\title{
UJI EFEK ANTIBAKTERI JAMUR ENDOFIT PADA TUMBUHAN SEREH (Cymbopogon citratus) PADA BAKTERI UJI Staphylococcus aureus DAN Escherichia coli
}

\author{
Fathia Falugah ${ }^{1)}$, Jimmy Posangi ${ }^{1)}$, Paulina Yamlean ${ }^{1)}$ \\ ${ }^{1)}$ Program Studi Farmasi FMIPA UNSRAT Manado, 95115
}

\begin{abstract}
Endophytic fungi are fungi that live in plant tissues and do not harm these plants. Endophytic fungi can produce compounds that have the potential as antibacterial. This study aimed to examine the antibacterial effects of endophytic fungi isolated from the lemongrass (Cymbopogon citratus) against Staphylococcus aureus and Escherichia coli bacteria. Lemongrass is used to inhibit or kill pathogenic bacteria because it contains essential oils that function as an antifungal and antibacterial against several pathogenic bacteria such as Staphylococcus aureus and Escherichia coli. The laboratory experiment method tested the antibacterial activity of endophytic fungi isolates obtained from lemongrass (Cymbopogon citratus) against Staphylococcus aureus and Escherichia coli using hole / well method. From the results of the study, four endophytic fungi were isolated from the roots and leaves of lemongrass (Cymbopogon citratus). Antibacterial results showed that endophytic fungi extract isolated from lemongrass plants was more effective in inhibiting Staphylococcus aureus compared to Escherichia coli bacteria. In Staphylococcus aureus bacteria the average inhibitory value is 5-9 $\mathrm{mm}$ while in Escherichia coli bacteria the average inhibitory value is only $3 \mathrm{~mm}$. Endophytic fungi from lemongrass roots have a better antibacterial effect compared to endophytic fungi from lemongrass leaves. Conclusion, endophytic fungi isolated from the roots and leaves of lemongrass (Cymbopogon citratus) have an antibacterial effect on the growth of $S$. aureus bacteria and are not effective against E. coli bacteria. This endophytic fungus isolate is more active against Gram positive (+) bacteria and less active against Gram negative (-) bacteria.
\end{abstract}

Keywords: Lemongrass plants, Endophytic Fungi, Antibacterial Activity, Staphylococcus aureus, Escherichia coli.

\begin{abstract}
ABSTRAK
Jamur endofit ialah jamur yang hidup di dalam jaringan tumbuhan dan tidak membahayakan tumbuhan tersebut. Jamur endofit dapat menghasilkan senyawa yang berpotensi sebagai antibakteri. Penelitian ini bertujuan untuk menguji efek antibakteri jamur endofit yang diisolasi dari akar,batang dan daun tumbuhan sereh (Cymbopogon citratus) terhadap bakteri Staphylococcus aureus dan Escherichia coli. Sereh digunakan untuk menghambat atau membunuh bakteri patogen karena mengandung minyak atsiri yang berfungsi sebagai antijamur dan antibakteri terhadap beberapa bakteri patogen seperti Staphylococcus aureus dan Escherichia coli. Metode penelitian secara eksperimen laboratorium menguji aktivitas antibakteri dari isolat jamur endofit yang diperoleh dari tumbuhan sereh (Cymbopogon citratus) pada bakteri Staphylococcus Aureus dan Escherichia Coli menggunakan metode lubang/sumuran. Dari hasil penelitan diperoleh empat jenis jamur endofit yang diisolasi dari akar dan daun tumbuhan sereh (Cymbopogon citratus). Hasil penelitian antibakteri menunjukkan bahwa ekstrak jamur endofit yang diisolasi dari tumbuhan sereh lebih efektif menghambat bakteri Staphylococcus aureus dibandingkan dengan bakteri Escherichia coli. Pada bakteri Staphylococcus aureus nilai rata-rata daya hambat yaitu 5-9 mm sedangkan pada bakteri Escherichia coli nilai rata-rata daya hambat yaitu hanya $3 \mathrm{~mm}$. Jamur endofit dari akar sereh memiliki efek antibakteri yang lebih baik dibandingkan dengan jamur endofit dari daun sereh. Kesimpulan, Jamur endofit yang diisolasi dari akar dan daun sereh (Cymbopogon citratus) memiliki efek antibakteri terhadap pertumbuhan bakteri $S$. aureus dan tidak efektiv terhadap bakteri $E$. coli. Isolat jamur endofit ini lebih aktif pada bakteri Gram positif (+) dan kurang aktif pada bakteri negatif (-).
\end{abstract}

Kata Kunci : Tumbuhan Sereh, Jamur Endofit, Aktivitas Antibakteri, Staphylococcus aureus, Escherichia coli. 
PHARMACON- PROGRAM STUDI FARMASI, FMIPA, UNIVERSITAS SAM RATULANGI,

Volume 8 Nomor 3 Agustus 2019

\section{PENDAHULUAN}

Kontaminasi mikroba pada saat ini adalah salah satu masalah yang dihadapi dalam kehidupan manusia yang berkaitan dengan penyebab penyakit infeksi. Beberapa jenis mikroba kontaminan, diketahui bahwa bakteri merupakan salah satu jenis mikroba yang tidak kalah penting dalam menyebabkan penyakit infeksi bagi manusia dalam kondisi tertentu. Karena salah satu sifatnya sebagai penyebab penyakit infeksi, maka beberapa jenis bakteri digolongkan dalam jenis bakteri patogen. Misalnya bakteri Escherichia coli, Staphylococcus aureus, dan bakteri penyebab infeksi penyakit lainnya. Jenis penyakit yang disebabkan oleh bakteri-bakteri patogen tersebut sangat beragam, sesuai dengan organ yang diserang atau diinfeksi (Brooks et all. 2001).

Penggunaan antibiotika merupakan salah satu cara yang dilakukan oleh manusia untuk mengobati penyakit akibat infeksi bakteri. Akan tetapi perlu diketahui bahwa penggunaan antibiotika yang berlebihan dan pemberian antibiotika dalam jangka waktu yang lama dapat menyebabkan terjadinya resistensi pada bakteri (Maryuni, 2008). Hal tersebut dapat menyebabkan bahan antibiotika sintesis menjadi tidak efektif lagi dan bahkan terkadang memberikan efek samping dalam penggunaanya (Nwinyi et al. 2009). Sebagai contoh bakteri S. epidermidis umumnya telah resisten terhadap antibiotik penisilin dan metisilin (Brook et all. 2001).

Salah satu pilihan alternatif pengganti antibiotika dengan menggunakan obat tradisional yang berasal dari tanaman sebagai obat alternatif terhadap infeksi bakteri. Penggunaan tanaman dalam terapi berbagai penyakit memiliki berbagai keuntungan diantaranya mengenai keamanan dan keefektifannya (Heyne,1987). Efek samping dari penggunaan obat herbal yang relatif lebih kecil dibanding penggunaan obat-obat kimia. Berbagai hasil penelitian yang mengkaji tentang penggunaan tanaman sebagai bahan obat telah banyak dilaporkan termasuk diantaranya sebagai antibakteri (Sudewo,2005).

Sereh digunakan untuk menghambat atau membunuh bakteri patogen karena mengandung minyak atsiri yang berfungsi sebagai antijamur dan antibakteri terhadap beberapa bakteri patogen, seperti Staphylococcus aureus, Bacillus cereus, Bacillus subtilis, Klebsiella pneumonia, Pseudomonas aeruginosa dan Escherichia coli yang telah diuji pada penelitian sebelumnya (Heyne,1987).

\section{METODOLOGI PENELITIAN}

\section{Waktu dan Tempat}

\section{Penelitian}

Penelitian dilaksanakan pada bulan April sampai Juni 2019 di Laboratorium Biologi Molekukuler dan Farmasetika Laut Fakultas Perikanan dan Ilmu Kelautan dan Laboratorium Farmasi Lanjutan Devisi Mikrobiologi Farmasi Program Studi Farmasi Fakultas Matematika dan Ilmu Pengetahuan Alam Universitas Sam Ratulangi Manado.

\section{Bentuk Penelitian}

Bentuk penelitian ini ialah eksperimental laboratorium yang akan menguji aktivitas antibakteri dari isolat jamur endofit yang diperoleh dari tumbuhan 
Sereh (Cymbopogon citratus) pada bakteri Staphylococcus Aureus dan Escherichia Coli menggunakan metode lubang/sumuran. Pengambilan sampel tumbuhan Sereh dilakukan diperkebunan pribadi di kelurahanan Maasing Kecamatan Tuminting Kota Manado Sulawesi Utara dengan ukuran $300 \mathrm{~m}^{2}$.

\section{Alat dan Bahan}

a. Alat

Alat-alat yang digunakan yaitu cawan petri,Erlenmeyer, autoklaf, gunting, pinset, kertas label, pemanas (kompor), oven, lampu spritus, kawat ose,timbangan analitik,gelas ukur, Laminar air flow, pecandang baja.

batang pengaduk, rak tabung reaksi, tabung reaksi, lemari pendingin, inkubator, mikropipet, digital caliper, kertas label, spidol permanen.

b. Bahan

Bahan-bahan yang digunakan yaitu, tumbuhan sereh,mikroba uji Staphylococcus aureus, Escherichia coli, PDA , Nutrient Agar (NA), alkohol 95\%, aquades, kloramfenikol kapsul $250 \mathrm{mg}$, beras, etil asetat, ekstrak jamur endofit dari tumbuhan Sereh, alumunium foil, kertas saring, kapas, $\mathrm{NaCl}$.

\section{Prosedur Penelitian \\ Preparasi Sampel}

Tanaman Sereh yg sudah diambil kemudian dibersihkan terlebih dahulu dilakukan proses sterilisasi permukaan yang diawali dengan pencucian sampel dibawah air mengalir kemudian perendaman dalam alkohol. Tujuan proses ini untuk menghilangkan mikroorganisme yang berada pada permukaan tumbuhan sehingga jamur yang tumbuh pada media isolasi merupakan jamur endofit (Resmi, 2011). Daun,batang dan akar Sereh yang diambil kemudian dipotong-potong dengan ukuran sekitar $1 \mathrm{~cm}$ menggunakan gunting steril (Michelle S,et al.2014).

\section{Sterilisasi Alat yang Digunakan}

Alat-alat yang digunakan dalam penelitian uji daya hambat ini disterilkan terlebih dahulu. Alat yang digunakan pada proses sterilisasi adalah oven dan autoclave. Oven digunakan untuk mensterilisasi alatalat untuk pembuatan media (cawan petri, ose, dan pinset). Autoklaf digunakan untuk mensterilisasi bahan-bahan pembuatan media dan alat gelas (Erlenmeyer, tabung reaksi, dan media).

\section{Pembuatan Media PDA dan PDA+AB}

Media PDA yang akan dibuat sesuai dengan kebutuhan nanti pada saat penelitian. Pada saat akan membuat media sebanyak 15 media PDA ditimbang sebanyak 11,7 gr dan ditambahkan NA sebanyak 3,6 gr dan dilarutkan kedalam $300 \mathrm{ml}$ aquades, 1 media diperlukan setidaknya $20 \mathrm{ml}$. PDA tadi dimasukan kedalam autoklaf untuk disterilisas dengan suhu $120^{\circ} \mathrm{c}$ selama 15 menit. Selanjutnya PDA tersebut kemudian dituangkan kedalam cawan petri yang sudah disterilisasi terlebih dahulu. Proses penuangan PDA dilakukan didalam alat luminar airflow agar tetap steril. Selama proses penuangan PDA, tangan harus dalam keadaan bersih. Setelah dituang, cawan petri harus langsung ditutup cawan petri agar tidak terkontaminasi oleh organisme dari luar. Proses pembuatan media PDA ini yaitu 
untuk digunakan pada saat isolasi jamur (miselia jamur) (Michelle et al.2014). Proses pembuatan media $\mathrm{PDA}+\mathrm{AB}$ juga sama seperti pembuatan media sebelumnya hanya saja disini PDA ditambahkan dengan antibiotik kloramfenikol sebanyak $150 \mathrm{ml}$. Tujuan penambahan antibiotik pada media PDA yaitu agar mencegah terjadinya pertumbuhan bakteri endofit pada media.

\section{Penanaman Sampel}

Sebelum ditanamkan kedalam media $\mathrm{PDA}+\mathrm{AB}$, direndam terlebih dahulu alat-alat dan sampel yang akan digunakan dalam larutan alkohol 95\% selama 30 detik untuk menghindari kontaminasi silang mikroba. Potongan sampel tersebut kemudian diangkat menggunakan pingset yg sudah direndam didalam larutan alkohol dan sudah dibakar selama 30 detik dengan menggunakan lampu spritus. Potongan ini selanjutnya ditanam pada media Potato Dextrose Agar (PDA)+AB di dalam cawan petri. Tiap cawan berisi empat potongan sampel. Cawan petri yang berisi sampel serai tersebut ditutup agar tidak terjadi kontaminasi oraganisme lain dari luar, kemudian disimpan pada suhu kamar $25^{\circ} \mathrm{C}$ selama 3 hari (Michelle et al.2014).

\section{Pemurnian Jamur Endofit}

Pada hari ketiga setelah penanaman sampel akan diamati jika sudah terlihat adanya miselia yang tumbuh dipermukaan media PDA+AB. Miselia yang sudah tumbuh diambil koloni yang terdapat pada permukaan media dengan kawat ose dan dipindahkan ke media PDA yang lain untuk ditumbuhkan kembali. Pemurnian ini bertujuan untuk mendapatkan 1 jenis jamur endofit yang murni. Simpan pada suhu ruangan selama $2 \times 24$ jam (Michelle et al.2014).

\section{Pembuatan Media Kulturnasi}

Pembuatan media ini menggunakan beras yang ditimbang sebanyak 40 gr dan aquades sebanyak $50 \mathrm{ml}$. Di masukkan kedalam Erlenmeyer untuk kemudian disterilisasikan kedalam autoklaf. Proses ini bertujuan juga agar beras tersebut bisa masak seperti memasak nasi. Autoklaf dilakukan selama 10-15 menit(hingga berasnya menjadi nasi) pada suhu $120^{\circ} \mathrm{c}$. Setelah itu didinginkan untuk dilakukan penanaman miselia pada media nasi (Yohanes et al.2017).

\section{Pemindahan miselia pada media kulturnasi}

Diambil miselia yang sudah tumbuh sebagian dari permukaan agar dengan cara dipotong memanjang dan dipotong lagi menjadi bagian-bagian kecil berbentuk segi empat. Kemudian dipindahkan ke media nasi. Sebelumnya alat yang akan digunakan untuk memotong harus disterilisasikan terlebih dahulu dengan di rendam didalam alkohol,ini bertujuan untuk mencegah terjadinya kontaminasi. Miselia didiamkan selama 7-14 hari untuk dilihat pertumbuhannnya (Yohanes et al.2017).

\section{Kultivasi dan Ekstraksi Jamur pada Media Nasi}

Kultur jamur pada media nasi secara statik selama 10 hari pada suhu ruang. Setelah pertumbuhan miselia jamur endofit mencapai bagian dasar dari labu erlenmeyer dilakukan ekstraksi. Proses ekstraksi 
dilakukan dengan cara maserasi dengan menambahkan larutan etil asetat sebanyak $200 \mathrm{ml}$ sampai semua nasi terendam lalu diaduk dengan shaker selama 24 jam. Setelah direndam dengan etil asetat selanjutnya disaring kemudian di evaporasi menggunakan Rotary vacuum evaporator pada suhu $40^{\circ} \mathrm{C}$ (Yohanes et al.2017).

\section{Ekstraksi}

Ekstraksi dilakukakan dengan cara maserasi yaitu jamur yang telah dikulturnasi direndam dengan cairan etil dan diaduk diatas alat shaker selama 24 jam. Sampel yang sudah direndam kemudian disaring menggunakan corong dan kertas saring dan menghasilkan filtrat 1 . Filtrate kemudian dimasukkan kedalam labu evaporator. Setelah evaporator dinyalakan dan semua alat terpasang atur suhu selama $40^{\circ} \mathrm{c}$, proses evaporasi kemudian dimulai. Setelah dilakukan evaporasi selama kurang lebih 20 menit dan didapatkannya ekstrak kemudian ditambahkan kembali dengan sedikit cairan alkohol 95\% untuk pengenceran ekstrak yang masih tersisa dan kemudian dievaporasi kembali agar diperoleh ekstrak kental. Ekstrak jamur yang didapatkan tersebut digunakan dalam pengujian daya hambat antibakteri (Michelle et al.2014).

\section{Pembuatan Larutan Suspensi Bakteri}

Bakteri yang telah dikultur pada agar miring diambil koloni dengan kawat ose steril dan dimasukkan ke dalam larutan $\mathrm{NaCl} 5 \mathrm{ml}$. Suspense bakteri dibuat dua, yang pertama Suspensi bakteri Staphylococcus Aureus dan kedua suspensi bakteri Escherechia Coli. Kedua suspense tersebut kemudian dituang kedalam masing- masing erlenmeyer yang telah terdapat NA yang sudah di autoklaf.

\section{Pembuatan Kontrol (Positif dan Negatif)}

Kontrol positif yang digunakan disini adalah kloramfenikol dan kontrol negative yaitu aquades. Kloramfenikol sebanyak 50 mg dilarutkan dalam $50 \mathrm{ml}$ aquades kemudian diencerkan hingga $10 \mathrm{ml}$.

\section{Pengujian aktivitas antibakteri}

Penanaman dilakukan masingmasing 4 ekstrak sampel di 4 tempat pada 1 cawan petri dengan jarak yang sama kemudian ditambahkan juga dengan kontorl positif dan kontrol negative, jadi jumlah sampel yang ada dalam 1 cawan petri yaitu 6 dimana 4 sampel adalah ekstrak jamur dan 2 sampel yaitu control postif dan kontrol negatif.

Kontrol positif yang digunakan disini adalah koramfenikol dan kontrol negatif yaitu aquades. Metode yang digunakan yaitu metode lubang/sumuran yaitu membuat lubang pada agar padat yang telah diinokulasi dengan bakteri. Pada lempeng agar yang telah diinokulasikan dengan bakteri uji dibuat suatu lubang yang selanjutnya diisi dengan zat antimikroba uji. Kemudian setiap lubang itu diisi dengan zat uji. Setelah diinkubasi pada suhu dan waktu yang sesuai dengan mikroba uji, dilakukan pengamatan dengan melihat ada atau tidaknya zona hambatan di sekeliling lubang (Prayoga, 2013).

\section{Pengamatan Pengukuran Zona Hambat} Pengamatan dilakukan 1x24 jam masa inkubasi. Daerah pada sekitaran sumuran menunujukan kepekaan mikroba 
terhadap antibiotic atau bahan antimikroba yang dgigunakan sebagai bahan uji yang dinyatakan dengan diameter zoba hambat atau zonqa bening.

Diameter zona hambat diukur dalam satuan millimeter ( $\mathrm{mm})$ menggunakan jangka sorong dengan cara mengukur jarak dari tepi sumur uji ke batas lingkaran zona hambat. Kemudian diameter zona hambat tersebut dikategorikan kekuatan daya anti bakterinya berdasarkan penggolongan Davis dan Stout (1971).

\section{HASIL DAN PEMBAHASAN}

\section{Isolat Jamur Endofit Akar dan daun Tumbuhan Sereh (cymbopogon citratus)}

Jamur endofit yang telah tumbuh di medium PDA kemudian dimurnikan ke dalam medium PDA baru dengan cara menginokulasi sedikit hifa dengan ose steril dari setiap koloni endofit yang berbeda. Media PDA bersifat selektif terhadap jamur dan mengandung kentang sebagai karbohidrat yang merupakan sumber nutrisi bagi pertumbuhan jamur (Ariyono et al. 2014). Kultur jamur endofit diinkubasi selama 3-7 hari pada suhu ruang. Pemurnian ini bertujuan untuk memisahkan koloni endofit dengan morfologi berbeda untuk dijadikan isolat tersendiri (Tilesky et al.2014). Pengamatan morfologi dilakukan selama 3-7 hari dan apabila masih ditemukan pertumbuhan koloni yang berbeda secara makroskopis, maka dilakukan pemurnian ulang hingga diperoleh isolate murni. Jamur endofit yang berhasil diisolasi dari tanaman inangnya dapat menghasilkan senyawa metabolit sekunder yang sama dengan yang dihasilkan oleh tanaman inangnya. Jamur endofit dikenal sebagai sumber metabolit sekunder berupa enzim atau senyawa bioaktif lainnya sehingga perlunya mengisolasi dan mengidentifikasi jamur endofit tersebut dari inangnya (Radji, 2010).

\section{Ekstraksi dan Kulturnasi Jamur Endofit}

Kultur jamur pada media nasi secara statik selama 10 hari pada suhu ruang dilakukan pada sampel dari akar dan daun Sereh dengan nama sampel (S.A.1.1) dan (S.A.2.1) dari sampel akar Sereh (S.D.1.1) dan (S.D.2.1) dari daun Sereh. Pada saat pertumbuhan miselia jamur endofit mencapai bagian dasar dari labu erlenmeyer dilakukan ekstraksi dengan cara maserasi. Maserasi merupakan proses perendaman sampel menggunakan pelarut organik pada temperatur ruangan. Proses ini sangat menguntungkan dalam isolasi senyawa bahan alam karena dengan perendaman sampel tumbuhan akan terjadi pemecahan dinding dan membran sel akibat perbedaan tekanan antara di dalam dan di luar sel, sehingga metabolit sekunder yang ada dalam sitoplasma akan terlarut dalam pelarut organik dan ekstraksi senyawa akan sempurna karena dapat diatur lama perendaman yang dilakukan. Pemilihan pelarut untuk proses maserasi akan memberikan efektivitas yang tinggi dengan memperhatikan kelarutan senyawa bahan alam dalam pelarut tersebut.

Proses ekstraksi dilakukan dengan cara maserasi dengan menambahkan larutan etil asetat sebanyak $200 \mathrm{ml}$ sampai semua nasi terendam lalu diaduk dengan shaker selama 24 jam. Metode maserasi digunakan karena cara pengerjaannya yang mudah 
dikerjakan dengan menggunakan peralatan yang sederhana, tidak menggunakan pemanasan dan dapat menarik senyawasenyawa aktif dari sampel dengan maksimal. Perendaaman sampel dalam maserasi dapat membuat dinding sel dari sampel pecah dan membuat senyawa-senyawa yang ada dalam sampel yang terdapat dalam sitoplasma akan tertarik oleh pelarut. Dinding sel pecah dikarenakan adanya perbedaan konsentrasi di dalam dan di luar sel. Konsentrasi diluar sel lebih tinggi dibandingkan konsentrasi di dalam sel yang rendah sehingga dinding sel pecah karena tidak bisa menahan tekanan dari perbedaan konsentrasi (Ariyani,2018).

Pada proses maserasi dilakukan pengocokan diatas alat shaker selama 24 jam agar pelarut dapat larut ke dalam sampel dan akan masuk ke rongga-rongga sampel karena keadaan diam selama maserasi menyebabkan turunnya perpindahan bahan aktif. Etil asetat adalah senyawa organik dengan rumus empiris $\mathrm{CH}_{3} \mathrm{COOC}_{2} \mathrm{H}_{5}$. Senyawa ini merupakan ester dari ethanol dan asam asetat. Senyawa ini berwujud cairan tak berwarna, memiliki aroma khas. Etil asetat adalah pelarut polar menengah yang volatil (mudah menguap), tidak beracun, dan tidak higroskopis. Setelah direndam dengan etil asetat selanjutnya disaring kemudian di evaporasi menggunakan Rotary vacuum evaporator pada suhu $40^{\circ} \mathrm{C}$ (Yohanes et al.2017). Proses evaporasi bertujuan untuk menguapkan ekstrak, penguapan ekstrak dimaksudkan agar air dan pelarut yang tersisa dalam ekstrak akan menguap. Menggunakan suhu $40^{\circ} \mathrm{C}$ bertujuan untuk tetap menjaga senyawa bioaktif dalam filtrate kerena biasanya senyawa-senyawa bioaktif rentan terhadap suhu tinggi (Brooks et al.2001).

\section{Pengujian aktivitas antibakteri dari ekstrak jamur endofit}

Pengujian aktivitas antibakteri dari ekstrak jamur endofit tumbuhan Sereh dilakukan pada bakteri Staphylococcus Aureus mewakili Gram postif dan Escherichia Coli mewakili gram negatif. Pengujian aktivitas bakteri ini menggunakan metode difusi (sumuran). Masing-masing ektsrak diujikan pada masing-masing bakteri. Metode difusi digunakan karena prosedurya sederhana mudah dan praktis untuk dikerjakan dan dapat melihat sensitivitas berbagai jenis mikroba terhadap antimikroba (Kowal et al.,2018).Penggunaan bakteri ini bertujuan melihat apakah ekstrak jamur endofit yang diisolasi dari tumbuhan Sereh memiliki aktivitas antibakteri terhadap mikroba pathogen pada tubuh manusia dan untuk mengetahui spectrum dari aktivitas antibakteri ekstrak jamur endofit tumbuhan Sereh memiliki spektrum luas (membunuh banyak jenis mikroba) atau spektrum sempit (membunuh salah satu mikroba).

Hasil yang diperoleh dalam uji aktivitas antibakteri dilakukan pengamatan selama 1x24 jam masa inkubasi dengan dilakukannya $3 \mathrm{x}$ pengulangan terhadapa bakteri S.Aureus dan 4x pengulangan untuk bakteri E.Coli. aktivitas yang terbentuk terlihat dengan adanya zona hambat (zona bening) disekitaran sumuran dengan ukuran pecandang baja $7 \mathrm{~mm}$, membuktikan bahwa ekstrak jamur endofit yang diambil dari sampel akar yang diuji menunjukan kepekaan terhadap salah satu bakteri yaitu 
S.Aureus dan antibiotik yang digunakan sebagai kontrol postif. Hasil uji aktivitas antibakteri dan hasil pengukuran diameter zona hambat ekstrak jamur endofit terhadap bakteri S.Aureus. Konsentrasi yang

\begin{tabular}{lccccc}
\multirow{2}{*}{ Sampel } & \multicolumn{5}{c}{ Ulangan } \\
\cline { 2 - 5 } & U1 & U2 & U3 & & \\
& & & & & \\
& & & & & \\
\hline S.A 1.1 & - & - & - & 7 & -
\end{tabular}

S.A $2.1 \quad 5 \mathrm{~mm} \quad 7 \mathrm{~mm} \quad 9 \mathrm{~mm} \quad 10$

S.D $1.12 \mathrm{~mm}$

S.D $2.11 \mathrm{~mm}$

digunakan yaitu $100 \%$ dengan banyaknya sampel yang diujikan yaitu $0,1 \mathrm{ml}$.

Tabel. 1. Aktivitas antibakteri pada bakteri S.Aureus (mm)

Hasil pengamatan aktivitas antibakteri pada bakteri uji S.Aureus memperlihatkan ekstrak jamur dari akar Sereh (S.A.1.1) tidak menunjukkan aktivitas antibakteri atau tidak ada zona hambat pada ketiga pengulangan sedangkan pada ektrak akar (S.A.2.1) terdapat aktivitas dengan adanya zona hambat disekitar bakteri uji dengan rata-rata ukuran sekitar 5$9 \mathrm{~mm}$ jumlah ini sudah dikurangi dengan besarnya pacandang yang digunakan yaitu 7 mm.. Pada ektrak jamur dari daun Sereh (S.D.1.1) pada ulangan 1 terdapat sedikit zona hambat yang terlihat yaitu sekitar 2 $\mathrm{mm}$, sedangkan pada ulangan dua dan tiga tidak ada aktivitas. Selanjutnya pada ekstrak jamur dari daun Sereh (S.D.2.1) terdapat zona hambat yang sangat kecil yaitu sekitar
$1 \mathrm{~mm}$. Pada kontrol positif yaitu kloramfenikol juga terdapat aktivitas yang bermakna yang terdapat disekitar bakteri uji sedangkan pada kontrol negative tidak terdapat aktivitas apapun pada ulangan 1-3.

Isolat jamur endofit yang berasal dari akar dan daun Sereh dan telah diujikan pada bakteri E.coli terdapat zona hambat yang tidak terlalu bermakna pada sampel akar

\begin{tabular}{llllllll}
\hline \multirow{2}{*}{ Sampel } & \multicolumn{7}{c}{ Ulangan } \\
\cline { 2 - 7 } & U1 & U2 & U3 & U4 & K (+) & K(-) \\
\cline { 2 - 6 } & & & & & & \\
\hline
\end{tabular}

S.A 2.1

S.D 1.1

S.D 2.1

(S.A.1.2) dan sampel daun (S.D.1.1).

Tabel. 2. Aktivitas antibakteri pada Escherichia Coli (mm)

Hasil ekstrak jamur endofit isolasi tumbuhan Sereh dari bakteri uji S.Aureus terlihat yang memberikan daya hambat yang paling besar terdapat pada ekstrak jamur endofit yang berasal dari akar Sereh dengan jumlah rata-rata yaitu 5-9 mm dengan kategori sedang. Hal ini menunjukan bahwa ekstrak jamur endofit dari akar Sereh memilki daya hambat yang lebih peka pada S.Aureus.

Diameter zona hambat terhadap bakteri Staphylococcus aureus lebih besar dibandingkan bakteri E. coli. Hasil yang berbeda ini dikarenakan adanya perbedaan struktur dinding sel kedua bakteri, dimana bakteri Gram negatif lebih kompleks dibandingkan dengan bakteri gram positif. Bakteri Gram negatif memiliki dinding sel 
yang terdiri dari 3 lapisan yaitu, lapisan luar, lapisan tengah dan lapisan dalam. Uji aktivitas penghambatan antibakteri terhadap bakteri Gram positif (S.Aureus) lebih kuat dibandingkan bakteri Gram negatif (E. coli). Hal ini sesuai dengan sifat dinding sel yang dimiliki bakteri tersebut. Gram positif hanya mempunyai lapisan tunggal pada dinding selnya (Sudewo, 2005). Struktur dinding sel bakteri Gram negatif yang relatif kompleks akan menyebabkan senyawa antibakteri lebih sukar masuk ke dalam sel dan menemukan sasaran untuk bekerja (Ariyani,2018).

Kontrol negatif yang digunakan yaitu aquades, terlihat dari hasil yang diperoleh aquades tidak menunjukan adanya zona hambat pada pengujian yang dilakukan pada masing-masing mikroba uji. $\mathrm{Hal}$ ini disebabkan karena aquades berfungsi mengetahui ada tidaknya pengaruh pelarut terhadap pertumbuhan bakteri sehingga dapat diketahui bahwa yang mempunyai aktivitas antibakteri adalah zat uji bukan pelarut. Berbalik dengan hasil yang ditujukan dari kontrol positif dari masingmasing mikroba uji terlihat kontrol postif menghasilkan aktivitas daya hambat yang besar dibandingkan dengan kontrol negatif. Kontrol postif yang digunakan yaitu kloramfenikol. Penggunaan kloramfenikol dikarenakan kloramfenikol merupakan antibiotik berspektrum luas. Hasil yang diperoleh bahwa pada bakteri S.Aureus menghasilkan daya hambat yang besar ditunjukan dengan hasil yang diperoleh yaitu 7 dan $10 \mathrm{~mm}$ dibandingakan denga bakteri E.Coli hal ini dikarenakan antibiotik kloramfenikol lebih peka terhadap bakteri S.Aureus (Gram positif), kloramfenikol hanya membutuhkan konsentrasi 0,2-5 $\mu \mathrm{g} / \mathrm{ml}$, sedangkan pada kebanyakan bakteri gram positif bakteri dihambat pada konsentrasi 1-10 $\mu \mathrm{g} / \mathrm{ml}$ (Katzung, 2004). Cara mengatasi infeksi bakteri ialah dengan antibiotik. Penggunaan antibiotik yang tidak rasional di berbagai bidang ilmu kedokteran merupakan salah satu penyebab timbulnya resistensi yang didapat (Nwinyi et al. 2009). Di sisi lain, penggunaan antibiotik juga sering menyebabkan efek samping seperti reaksi alergi, reaksi idiosinkrasi, reaksi toksik, serta perubahan biologis dan metabolis pada hospes (Prayoga, 2013). Keadaan tersebut mendorong untuk mencari alternatif pengobatan yang relatif lebih efektif dan aman, antara lain dengan pemanfaatan obat dari bahan alam (Putri, 2014). Alasan inilah yang mendorong peneliti mengambil bahan alam Sereh sebagai bahan yang akan diujikan untuk aktivitas antibakteri. Tumbuhan memiliki senyawa-senyawa aktif yang dapat digunakan sebagai antibiotik sehingga eksplorasi senyawa-senyawa aktif tersebut memiliki relevansi yang besar terkait penemuan antibiotik baru untuk mengatasi resistensi. Selain itu, penggunaan antibiotik dari senyawa tumbuhan dapat lebih aman untuk tubuh pada penggunaan jangka panjang (Putri,2014).

\section{KESIMPULAN}

Berdasarkan penelitian dapat disimpulkan bahwa ekstrak jamur endofit yang diisolasi dari akar Sereh memiliki aktivitas antibakteri pada bakteri uji S.Aureus dan tidak memiliki aktivitas antibakteri pada bakteri E.Coli. Dimana aktivitas yang dihasilkan pada bakteri Staphylococcus aureus tergolong aktivitas yang sedang dan lemah, sedangkan untuk Escherichia coli tidak adanya kepekaan 
aktivitas antibakteri untuk itu tidak terdapat zona bening pada saat pengujian.

\section{SARAN}

Berdasarkan hasil dan pembahasan aktivitas antibakteri ekstrak jamur endofit yang diisolasi dari tumbuhan Sereh maka dapat diberikan saran yaitu perlu dilakukan penelitian lebih lanjut tentang uji antibakteri dengan metode pengujian yang berbeda atau dengan menggunakan bakteri uji yang berbeda.

\section{DAFTAR PUSTAKA}

Ariyani, F., Setiawan, L.E., dan F.E.

Soetaredjo. 2008. Ekstraksi Minyak Atsiri dari Tanaman Sereh dengan Menggunakan Pelarut Metanol Aseton dan N Heksana. Widya Teknik. Vol. VII (2) : 124-133.

Brooks, G.F., Janet, S.B., Stephen A.M. 2001. Jawetz, Melnick and Adelbergs, Mikrobiologi Kedokteran, Alih Bahasa oleh Mudihardi, E., Kuntaman, Wasito, E.B., Mertaniasih, N.M., Harsono, S., dan Alimsardjono, L.Jakarta : Penerbit Salemba Medika.

Heyne, K.,1987.Tumbuhan Berguna Indonesia, Volume II, Yayasan Sarana Wana Jaya : Diedarkan oleh Koperasi Karyawan, Badan Litbang Kehutanan, Jakarta.

Katzung, B. G., 2004. Farmakologi Dasar dan Klinik. Edisi XIII. Buku 3. Translationof Basic and Clinical Pharmacology Eight Edition Alih bahasa oleh BagianFarmakologi
Fakultas kedokteran Universitas Airlangga. Jakarta: SalembaMedika

Michelle Sumampouw,et al.2014.Uji Efek Antibakteri Jamur Endofit Akar Bakau Rhizophora Stylosa Terhadap Bakteri Staphylococcus Aureus Dan Escherichia Coli.Jurnal e-Biomedik. $\operatorname{Vol}(2)$ No (1)

Nwinyi, Obinna C., Chinedu, Nwodo S., Ajani, Olayinka, Chinwe I., Ogunniran \& Kehinde, O. 2009. Antibacterial effects of extracts of Ocimum gratissimum and Piper guineense on Escherichia coli and Staphylococcus aureus. African Journal of Food Science. 3 (3) : 022025 .

Prasetyono.D.S. 2012. A- Z Daftar Tanaman Obat Ampuh di Sekitar Kita. Jogjakarta : FlasBooks.

Prayoga E. 2013. Perbandingan Efek Ekstrak Daun Sirih Hijau (Piper betle L.) dengan Metode Difusi Disk dan Sumuran terhadap Pertumbuhan Bakteri Staphylococcus aureus. Universitas Islam Negeri Syarif Hidayatullah. Skripsi. Jakarta.

Putriningtyas, D. 2014. Aktivitas Antibakteri Minyak Atsiri Daun Sirih Merah (Piper crocatum ruiz \& pav.) dan Minyak Atsiri Daun Sereh Wangi (Cymbopogon nardus (L.) rendle) Asal Tawangmangu Terhadap Bakteri Staphylococcus aureus dan Escherichia coli. Univ. Muhamadyah. Surakarta. 
PHARMACON- PROGRAM STUDI FARMASI, FMIPA, UNIVERSITAS SAM RATULANGI,

Radji, Maksum. 2010. Buku Ajar Mikrobiologi Panduan Mahasiswa Farmasi dan Kedokteran. Jakarta: EGC.

Resmi Mustarichie dkk.2011. Metode Penelitian Tanaman Obat, Widya Padjadjaran. Bandung.

Sudewo, B. 2005. Basmi penyakit dengan sirih merah. Jakarta: Agromedia Pustaka

Tilesky Phoamda,et al.2014. Uji Efek Antibakteri Jamur Endofit Akar Bakau (Bruguiera gymnorhiza) Terhadap Bakteri Staphylococcus Aureus Dan Escherichia Coli. Jurnal e-Biomedik. Vol(2) No (1)

Yohanis Nawea,et al.2017. Uji Antibakteri Jamur Endofit Dari Tumbuhan Mangrove Soneratia alba Yang Tumbuh Di Perairan Pantai Tanah Wangko. Jurnal Pesisir dan Laut Tropis. Vol (1) No(1). 